\title{
PENERAPAN TERAPI RELAKSASI BENSON PADA PASIEN \\ PRE OPERASI YANG MENGALAMI KECEMASAN DI RUANG TERATAI RSUD dr. CHASBULLAH ABDULMAJID KOTA BEKASI
}

\section{APPLICATION OF BENSON RELAXATION THERAPY IN PATIENTS THAT HAVE PRE OPERATION OF ANXIETY IN THE TERATAI dr. CHASBULLAH ABDULMAJID BEKASI CITY}

\author{
Riza Roxiana ${ }^{1}$, Hani Fauziah ${ }^{2}$, Ashar Prima $^{2 *}$ \\ ${ }^{1}$ Jurusan Diploma III Keperawatan Sekolah Tinggi Ilmu Kesehatan Bani Saleh Bekasi Indonesia \\ ${ }^{2}$ Sekolah Tinggi Ilmu Kesehatan Bani Saleh Bekasi Indonesia \\ asharprima25@gmail.com* \\ *Corresponding author*
}

\begin{abstract}
ABSTRAK
Tindakan pembedahan di Indonesia menempati urutan ke-11 dari 50 pertama penanganan penyakit di rumah sakit se Indonesia dengan pasien operasi sebanyak 1,2 juta jiwa.Ansietas atau kecemasan merupakan salah satu masalah yang sering ditemukan pada pasien yang akan mengalami proses pembedahan. Pasien yang mengalami kecemasan berkepanjangan sebelum operasi jika tidak ditangani dapat mengakibatkan tidak terlaksana atau dibatalkan tindakan operasi. Mengurangi tingkat kecemasan perawat melakukan terapi relaksasi benson sebagai tindakan non farmakologi. Kriteria subjek berusia 20 tahun sampai 55 tahun, dengan tingkat kecemasan sedang (40-60) dan tingkat kecemasan berat (70-90). Metode dalam penulisan penelitian ini menggunakan motode deskriptif dalam bentuk studi kasus tentang tingkat kecemasan pasien pre operasi sebelum dan sesudah diberikan terapi relaksasi benson, pada 6 subjek. Instrument yang digunakan adalahlembar Visual Analog Scale Anxiety (VAS-A)dan diperkuat dengan lembar observasi kecemasan. Hasil studi kasus bahwa hanya 4 pasien yang berhasil mengalami penurunan kecemasan dikarenakan pasien tampak tenang dan rileks serta mudah untuk berkosentrasi, 2 pasien tidak berhasil dikarenakan sulit berkonsentrasi dan tidak tenang. Relaksasi benson sebagai alternatif terapi non farmakologis yang dapat diberikan kepada pasien pre operasi untuk menurunkan kecemasan.
\end{abstract}

Kata Kunci : Pre Operasi, Relaksasi Benson, Kecemasan 


\begin{abstract}
ABSTRAK
Surgery in Indonesia ranks 11 out of 50 first treatment of diseases in hospitals across Indonesia with surgery patient a total of 1.2 million people. Anxiety is one issue that is often found in patients who will undergo surgery. Patients who experience prolonged anxiety before surgery if left untreated can result in not performing or canceled surgery. Reduce anxiety levels of nurses do Benson relaxation therapy as non-pharmacological measures. Criteria subjects aged 20 years to 55 years, with a moderate level of anxiety (40-60) and the rate of severe anxiety (70-90). Methods in writing of this research using descriptive method possible in the form of case studies of patients with preoperative anxiety levels before and after Benson relaxation therapy, in 6 subjects. The instrument used was a sheet Visual Analogue Scale Anxiety (VAS-A) and strengthened by the observation sheet anxiety. The results of case studies that only 4 patients were successfully decreased patient anxiety due to appear calm and relaxed and easy to concentrate, 2 patients did not succeed due to difficulty concentrating and unsettled. Benson relaxation as an alternative non-pharmacological therapies that can be administered to patients to reduce preoperative anxiety.
\end{abstract}

Keywords

: Pre-Surgery, Benson Relaxation, Anxiety

\title{
PENDAHULUAN
}

Proses pembedahan merupakan suatu tindakan pengobatan yang dapat menimbulkan gangguan psikologis yaitu kecemasan. Pada tahap pre operasi rasa cemas biasanya timbul ketika pasien mengantisipasi pembedahan dan diikuti dengan rasa cemas pada tahap pasca operasi seperti nyeri atau rasa tidak nyaman, perubahan citra tubuh dan fungsi tubuh, perubahan pada pola hidup dan masalah finansial (Mardiani, 2014). Ansietas atau kecemasan merupakan suatu respons adaptif yang normal terhadap stres karena pembedahan. Pada tahap pre operasi rasa cemas biasanya timbul ketika pasien mengantisipasi pembedahan dan diikuti dengan rasa cemas pada tahap pascaoperasi seperti nyeri atau rasa tidak nyaman, perubahan citra tubuh dan fungsi tubuh, perubahan pada pola hidup dan masalah finansial (Utama, 2013).

Data yang diperoleh dari badan penelitian kesehatan dunia World Health Organization (WHO) jumlah pasien dengan tindakan operasi tercatat pada tahun 2011 terdapat 140 juta jiwa di seluruh rumah sakit di dunia, data pada tahun 2012 mengalami peningkatan sebesar 148 juta jiwa, sedangkan di tahun 2015 terdapat 160 juta jiwa di dunia yang melakukan tindakan pembedahan. Hasil Kementrian Kesehatan Republik Indonesia (Kemenkes) tahun 2015 menyatakan bahwa pada tahun 2012 terdapat 148 juta jiwa pasien diseluruh rumah sakit di dunia pasien dengan tindakan operasi, sedangkan di Indonesia tindakan pembedahan menempati urutan ke-11 dari 50 pertama penanganan penyakit di rumah sakit se Indonesia dengan pasien operasi sebanyak 1,2 juta jiwa.

Pasien yang mengalami kecemasan berkepanjangan sebelum operasi jika tidak ditangani dapat mengakibatkan tidak terlaksana atau dibatalkan dikarenakan memberikan efek terhadap psikologis, dan aspek fisiologis seperti timbulnya, takikardia, peningkatan tekanan darah, mual, dan berkeringat. Apabila tekanan 
darah naik dan tetap dilakukan operasi dapat mengganggu efek dari obat anastesi dan dapat menyebabkan pasien terbangun kembali ditengah-tengah operasi (Sari, 2017).

Upaya untuk mengatasi kecemasan pada pasien pre operasi dapat dilakukan melalui dua cara yaitu dengan terapi farmakologis dan terapi non farmakologis. Salah satu jenis terapi non farmakologis yang bisa digunakan adalah teknik relaksasi benson. Relaksasi Benson merupakan pengembangan metode respon relaksasi pernafasan dengan melibatkan faktor keyakinan pasien, yang dapat menciptakan suatu lingkungan internal sehingga dapat membantu pasien mencapai kondisi kesehatan dan kesejahteraan yang lebih tinggi. Kelebihan latihan relaksasi benson adalah latihan relaksasi lebih mudah dilakukan bahkan dalam kondisi apapun serta tidak memiliki efek samping apapun (Datak 2009).

Hasil penelitian yang dilaporkan oleh Ferlina (2009) menunjukkan bahwa $80 \%$ pasien pre operasi mengalami kecemasan dan $60 \%$ mengalami kecemasan sedang dan berat. Penelitian lain dilakukan oleh Nataliza (2011) ditemukan 20 $(64,5 \%)$ pasien mengalami kecemasan ringan dan $11(35,5 \%)$ mengalami kecemasan berat.

Salah satu terapi non farmakologi yang dapat diterapkan adalah terapi relaksasi benson untuk menurunkan tingkat kecemasan pada pasien pre operasi. Terapi relaksasi benson memiliki kelebihan yaitu membuat hati tentram, dapat mengurangi rasa cemas, khawatir dan gelisah, detak jantung lebih rendah, dan mengurangi tekanan darah dan tidur terlelap, serta membantu individu dalam mengontrol diri dan memfokuskan perhatian sehingga dapat berpikir logis dalam situasi yang menegangkan (Aspiani 2014).

Uraian fakta di atas mendorong penulis untuk melakukan studi kasus tentang penerapan terapi relaksasi benson pada pasien pre operasi, membuat penulis tertarik menerapkan terapi relaksasi benson pada pasien pre operasi untuk menilai penurunan kecemasan.

\section{METODE PENELITIAN}

Penelitian ini menggunakan metode deskriptif dalam bentuk studi kasus pada pasien pre operasi yang mengalami kecemasan. Kriteria subjek dalam penelitian ini yaitu pasien yang berusia 20 tahun sampai 55 tahun dan pasien dengan tingkat kecemasan sedang (40-60) dan tingkat kecemasan berat (70-90).

Kegiatan ini dilakukan sehari sebelum subjek melakukan operasi sebanyak 1 kali dan selama 10 menit. Setelah 5 menit dilakukan terapi relaksasi benson kepada subjek pre operasi lalu dilakukan observasi untuk menilai penurunan kecemasan akibat operasi yang akan dijalani lalu dicatat dalam lembar observasi oleh penulis. Setelah dilakukan implementasi keperawatan dengan terapi relaksasi benson, selanjutnya penulis melakukan evaluasi terhadap penurunan kecemasan pada pasien pre operasi. 
Penelitian ini menggunakan instrumen Visual Analog Scale Anxiety (VASA) untuk mengukur tingkat kecemasan pasien dan spigmomanometer. Selain itu, penulis juga menggunakan lembar persetujuan menjadi subjek, lembar informed consent, lembar observasi untuk mengetahui tingkat kecemasan pasien, lembar observasi karakteristik kecemasan, dan lembar standar operasional prosedur relaksasi benson.

Berdasarkan komite etik penelitian No. 25/KEP-LPPM/STIKES$\mathrm{BS} / \mathrm{V} / 2019$ sudah menyatakan untuk lolos kaji etik dalam melakukan penelitian

\section{HASIL DAN PEMBAHASAN}

Penelitian ini melibatkan 6 pasien pre operasi yang mengalami kecemasan,ke-enam subjek sudah sesuai dengan kriteria yang ditetapkan dalam studi kasus ini. Hasil gambaran 6 subjek dijabarkan sebagai berikut:

\section{Subjek 1}

Hasil yang didapatkan pada subjek 1 sebelum dilakukan terapi relaksasi benson yaitu pasien terlihat cemas dan gelisah, skor kecemasan 60 (kecemasan sedang), hasil pemeriksaan tanda-tanda vital yaitu tekanan darah 110/80 $\mathrm{mmHg}$, napas $20 \mathrm{x} /$ menit, nadi $80 \mathrm{x} / \mathrm{menit}$, dan suhu $36,2^{\circ} \mathrm{C}$. Hasil yang didapatkan pada subjek 1 setelah dilakukan terapi relaksasi benson yaitu subjek mengatakan rileks dengan skor kecemasan 50 (kecemasan sedang), hasil pemeriksaan tanda-tanda vital yaitu tekanan darah 100/70 $\mathrm{mmHg}$, napas $18 \mathrm{x} /$ menit, nadi $75 \mathrm{x} / \mathrm{menit}$, dan suhu $36,0^{\circ} \mathrm{C}$.

\section{Subjek 2}

Hasil yang didapatkan pada subjek 2 sebelum dilakukan terapi relaksasi benson yaitu subjek mengatakan takut dan trauma untuk menjalankan operasi yang kedua kali, terlihat cemas dan gelisah, dengan skor kecemasan 70 (kecemasan berat), hasil pemeriksaan tanda-tanda vital yaitu tekanan darah 140/90 $\mathrm{mmHg}$, napas $21 \mathrm{x} / \mathrm{menit}$, nadi $89 \mathrm{x} /$ menit, dan suhu $36,6^{\circ} \mathrm{C}$. Hasil yang didapatkan pada subjek 2 setelah dilakukan terapi relaksasi benson yaitu subjek mengatakan rileks dan merasa tenang, skor kecemasan 60 (kecemasan sedang), hasil pemeriksaan tanda-tanda vital yaitu tekanan darah 130/80 $\mathrm{mmHg}$, napas 18 $\mathrm{x} / \mathrm{menit}$, nadi $80 \mathrm{x} / \mathrm{menit}$, dan suhu $36,6^{\circ} \mathrm{C}$.

\section{Subjek 3}

Hasil yang didapatkan pada subjek 3 sebelum dilakukan terapi relaksasi benson yaitu dengan skor kecemasan 50 (kecemasan sedang), ditandai dengan terlihat cemas dan gelisah, hasil pemeriksaan tanda-tanda vital yaitu tekanan darah $130 / 90 \mathrm{mmHg}$, napas $24 \mathrm{x} /$ menit, nadi $88 \mathrm{x} / \mathrm{menit}$, dan suhu $36,5^{\circ} \mathrm{C}$. Hasil yang didapatkan pada subjek 3 setelah dilakukan terapi relaksasi benson yaitu subjek mengatakan masih cemas dan sulit berkonsentrasi karena nyeri yang di rasakan, skor kecemasan 50 (kecemasan sedang), hasil pemeriksaan tanda-tanda vital yaitu tekanan darah 130/90 mmHg, napas $24 \mathrm{x} /$ menit, nadi $89 \mathrm{x} /$ menit, dan suhu 36, $5^{\circ} \mathrm{C}$. 


\section{Subjek 4}

Hasil yang didapatkan pada subjek 4 sebelum dilakukan terapi relaksasi benson yaitu subjek mengatakan takut tentang operasi yang akan dijalani, subjek terlihat gelisah dan cemas, skor kecemasan 70 (kecemasan berat), hasil pemeriksaan tanda-tanda vital yaitu tekanan darah $110 / 70 \mathrm{mmHg}$, napas 20 $\mathrm{x} /$ menit, nadi $82 \mathrm{x} / \mathrm{menit}$, dan suhu $36,9^{\circ} \mathrm{C}$. Hasil yang didapatkan pada subjek 4 setelah dilakukan terapi relaksasi benson yaitu subjek mengatakan rileks, merasa tenang, dan sudah berkurang rasa takut, skor kecemasan 50 (kecemasan sedang), hasil pemeriksaan tanda-tanda vital yaitu tekanan darah 100/70 $\mathrm{mmHg}$, napas 16 $\mathrm{x} /$ menit, nadi $72 \mathrm{x} /$ menit, dan suhu $36,9^{\circ} \mathrm{C}$.

\section{Subjek 5}

Hasil yang didapatkan pada subjek 5 sebelum dilakukan terapi relaksasi benson yaitu dengan subjek mengatakan gelisah dan sulit tidur, skor kecemasan 40 (kecemasan sedang), hasil pemeriksaan tanda-tanda vital yaitu tekanan darah $120 / 80 \mathrm{mmHg}$, napas $18 \mathrm{x} / \mathrm{menit}$, nadi $68 \mathrm{x} / \mathrm{menit}$, dan suhu $36,5^{\circ} \mathrm{C}$. Hasil yang didapatkan pada subjek 5 setelah dilakukan terapi relaksasi benson yaitu subjek mengatakan sulit berkonsentrasi karena lingkungan yang tidak nyaman (berisik), skor kecemasan 40 (kecemasan sedang), hasil pemeriksaan tanda-tanda vital yaitu tekanan darah 120/70 mmHg, napas $20 \mathrm{x} /$ menit, nadi $72 \mathrm{x} /$ menit, dan suhu $36,5^{\circ} \mathrm{C}$.

\section{Subjek 6}

Hasil yang didapatkan pada subjek 6 sebelum dilakukan terapi relaksasi benson yaitu dengan subjek mengatakan cemas akan dilakukan tindakan operasi, skor kecemasan 40 (kecemasan sedang), hasil pemeriksaan tanda-tanda vital yaitu tekanan darah 110/80 mmHg, napas $20 \mathrm{x} /$ menit, nadi $76 \mathrm{x} /$ menit, dan suhu $36,{ }^{\circ} \mathrm{C}$. Hasil yang didapatkan pada subjek 6 setelah dilakukan terapi relaksasi benson yaitu subjek mengatakan lebih rileks, dengan skor kecemasan 30 (kecemasan ringan), hasil pemeriksaan tanda-tanda vital yaitu tekanan darah 100/70 $\mathrm{mmHg}$, napas $20 \mathrm{x} / \mathrm{menit}$, nadi $70 \mathrm{x} / \mathrm{menit}$, dan suhu $36,7^{\circ} \mathrm{C}$.

Gambaran tingkat kecemasan sebelum dan sesudah tindakan dapat dilihat pada gambar dibawah ini:

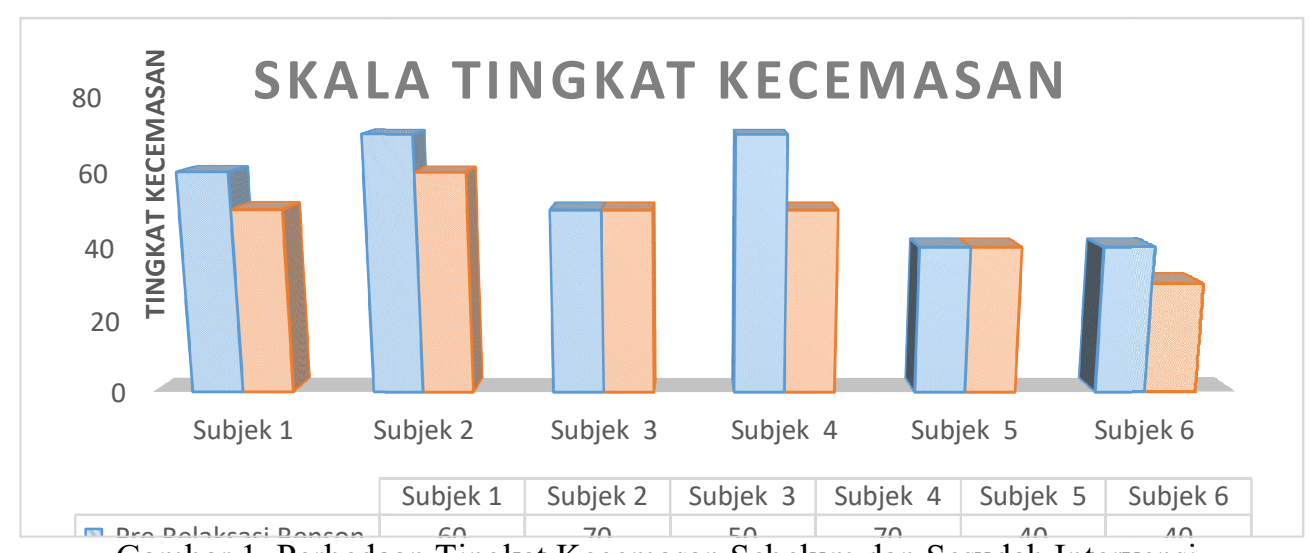

Gambar 1. Perbedaan Tingkat Kecemasan Sebelum dan Sesudah Intervensi 
Dapat dilihat bahwa dari 6 subjek yang tidak mengalami penurunan kecemasan sebanyak 2 subjek. Penurunan kecemasan yang tertinggi yaitu sebesar 20 dan penurunan kecemasan yang terendah yaitu sebesar 10. Rata-rata subjek mengalami penurunan sebesar 10 .

Hasil sebelum dilakukan intervensi keperawatan terapi relaksasi benson pasien mnegalami kecemasan sedang sampai dengan berat. Setelah diberikan terapi relaksasi benson dengan durasi 10 menit, pasien mengalami penurunan hingga turun satu angka sampai dua angka dan mengalami perubahan tingkat kecemasan. Dari enam pasien diperoleh hasil empat pasien mengalami penurunan tingkat kecemasan, sedangkan dua pasien tidak mengalami penurunan kecemasan dikarenakan pasien ke tiga mengalami nyeri hebat pada abdomen dan pasien ke lima lingkungan yang tidak nyaman (berisik).

Hasil penelitian ini menunjukan bahwa setelah dilakukan terapi relaksasi benson pada subjek pre operasi yang mengalami kecemasan dapat diperoleh hasil adanya penurunan kecemasan yang dirasakan dengan skor rata-rata menurun hingga 10 sampai 20. Didapatkan hasil bahwa dari 6 subjek yang dilakukan tindakan terapi relaksasi benson hanya 4 subjek yang berhasil mengalami penurunan kecemasan, 3 subjek mengalami penurunan kecemasan dengan skor 10, 1 subjek mengalami penurunan kecemasan dengan skor 20, 2 subjek tidak mengalami penurunan kecemasan dikarenakan subjek 3 mengalami nyeri hebat pada abdomen dengan diagnosis colic abdomen dan subjek 5 sulit berkonsentrasi dikarenakan lingkungan yang tidak nyaman (berisik). Pada 4 subjek yang mengalami penurunan tingkat kecemasan dikarenakan saat diberikan terapi relaksasi benson subjek tampak tenang dan rilek serta mudah untuk berkosentrasi sehingga terapi relaksasi benson yang diberikan berhasil.

Relaksasi merupakan suatu metode dan cara yang dapat digunakan dan diberikan kepada pasien pre operasi sebelum dilakukannya tindakan operasi dengan relaksasi pasien dapat melepaskan rasa ketegangan, dan stres yang dialaminya karena dengan melakukan relaksasi, pasien akan mengalihkan rasa cemasnya. Setelah dilakukan teknik relaksasi terjadi penurunan gejala kecemasan yang dirasakan pasien. Saat pasien dalam keadaan rileks terjadi penurunan hormon kortisol dan adrenalin serta peningkatan hormon endorphin dan serotonin. Peningkatan hormon endorphin dan serotonin berefek pada respon fisologis pasien yang ditunjukkan dengan perasaan pasien menjadi lebih tenang, tidak khawatir, terjadi penurunan detak jantung pasien, penurunan denyut nadi, tidak gelisah dan lain sebagainya (Yulistiani, 2015).

Hasil penelitian serupa dilaporkan oleh Sari (2017), bahwa teknik terapi relaksasi benson yang dilakukan di RSUD dr. Achmad Mochtar Bukittinggi mengalami penurunan kecemasan. Sebelum dilakukan teknik relaksasi benson pada subjek pre operasi diperoleh hasil yaitu subjek mengalami kecemasan sedang dengan presentasi 33,3\%, mengalami kecemasan berat dengan presentasi $50 \%$, dan mengalami panik dengan presentasi $16,7 \%$. Setelah dilakukan teknik relaksasi benson tingkat kecemasan subjek pre operasi mengalami penurunan yaitu $50 \%$ mengalami cemas ringan, 33,3\% mengalami cemas sedang, dan 16,7\% mengalami cemas berat. Hasil penelitian lainnya dilaporkan oleh Mardiani (2014), teknik 
terapi relaksasi benson yang dilakukan di RSUD Kota Salatiga mengalami penurunan kecemasan. Sebelum dilakukan teknik relaksasi benson pada subjek pre operasi diperoleh hasil yaitu subjek yang mengalami kecemasan ringan dengan presentase $52,4 \%$ dan kecemasan sedang dengan presentase $47,6 \%$ Setelah dilakukan intervensi terapi relaksasi benson pasien mengalami penurunan kecemasan yaitu kecemasan ringan dengan presentase 33, 3\% dan normal dengan presentase $66,7 \%$.

\section{KESIMPULAN}

Penerapan terapi relaksasi benson mampu menurunkan kecemasan pada pasien pre operasi. Penurunan kecemasan yang tertinggi yaitu sebesar 20 dan penurunan kecemasan yang terendah yaitu sebesar 10. Rata-rata subjek mengalami penurunan sebesar 10 .

\section{SARAN}

Diharapkan pemberian teknik relaksasi benson ini dapat bermanfaat bagi pasien dan juga bagi tenaga perawat dalam memberikan asuhan keperawatan dalam penatalaksanaan kecemasan secara non farmakologi. Terapi relaksasi benson dapat dilakukan secara mandiri oleh pasien ataupun dilakukan oleh perawat serta dijadikan sebagai terapi alternatife komplementer dalam asuhan keperawatan sebagai tindakan mandiri keperawatan untuk mengurangi kecemasan pada pasien pre operasi.

\section{DAFTAR PUSTAKA}

Aspiani. (2014). Buku Ajar Asuhan Keperawatan Gerontik Jilid 2. Jakarta Timur: CV. Trans Info Media.

Datak. (2009). Penurunan Nyeri Pasca Bedah Pasien TUR Prostat Melalui Relaksasi Benson.Jurnal Keperawatan Indonesia Volume 12, Nomor 3, 174-178.

Kemenkes. (2015). Masalah Kesehatan Masyarkat Indonesia tahun 2015. Jakarta: Kemenkes.

Mardiani. (2014). Perbedaan Efektifitas Teknik Relaksasi Benson dan Nafas Dalam Terhadap Tingkat Kecemasan Pasien Pre Operasi Bedah Abdomen di RSUD Kota Salatiga. Jurnal Ilmu Keperawatan dan Kebidanan, 1-7.

Sari. (2017). Pengaruh Teknik Relaksasi Terhadap Penurunan Tingkat Kecemasan Pasien Pre Operatif. Menara Ilmu Volume XI Jilid 1 No. 75, 13-24.

Utama. (2013). Buku Ajar Psikiatri Edisi Kedua. Jakarta: Badan Penerbit FKUI. 
Yulistiani. (2015). Teknik Relaksasi Untuk Menurunkan Gejala Kecemasan Pada Pasien Pre Operasi. Seminar Nasional Universitas Muhammadiyah Purwokerto, 131-138. 